\title{
Sexual Dimorphism, Age, and Fat Mass Are Key Phenotypic Drivers of Proteomic Signatures
}

Citation for published version (APA):

Curran, A. M., Fogarty Draper, C., Scott-Boyer, M-P., Valsesia, A., Roche, H. M., Ryan, M. F., Gibney, M. J., Kutmon, M., Evelo, C. T., Coort, S. L., Astrup, A., Saris, W. H., Brennan, L., \& Kaput, J. (2017). Sexual Dimorphism, Age, and Fat Mass Are Key Phenotypic Drivers of Proteomic Signatures. Journal of

Proteome Research, 16(11), 4122-4133. https://doi.org/10.1021/acs.jproteome.7b00501

Document status and date:

Published: 03/11/2017

DOI:

10.1021/acs.jproteome.7b00501

Document Version:

Publisher's PDF, also known as Version of record

Document license:

Taverne

Please check the document version of this publication:

- A submitted manuscript is the version of the article upon submission and before peer-review. There can be important differences between the submitted version and the official published version of record.

People interested in the research are advised to contact the author for the final version of the publication, or visit the DOI to the publisher's website.

- The final author version and the galley proof are versions of the publication after peer review.

- The final published version features the final layout of the paper including the volume, issue and page numbers.

Link to publication

\footnotetext{
General rights rights.

- You may freely distribute the URL identifying the publication in the public portal. please follow below link for the End User Agreement:

www.umlib.nl/taverne-license

Take down policy

If you believe that this document breaches copyright please contact us at:

repository@maastrichtuniversity.nl

providing details and we will investigate your claim.
}

Copyright and moral rights for the publications made accessible in the public portal are retained by the authors and/or other copyright owners and it is a condition of accessing publications that users recognise and abide by the legal requirements associated with these

- Users may download and print one copy of any publication from the public portal for the purpose of private study or research.

- You may not further distribute the material or use it for any profit-making activity or commercial gain

If the publication is distributed under the terms of Article $25 \mathrm{fa}$ of the Dutch Copyright Act, indicated by the "Taverne" license above, 


\section{Sexual Dimorphism, Age, and Fat Mass Are Key Phenotypic Drivers of Proteomic Signatures}

Aoife M. Curran, ${ }^{\dagger, \text { II }}$ Colleen Fogarty Draper, ${ }^{\ddagger, \S, \text { II }}$ Marie-Pier Scott-Boyer, " Armand Valsesia, Helen M. Roche,,$^{\dagger, \perp}$ Miriam F. Ryan, ${ }^{\dagger}$ Michael J. Gibney, ${ }^{\dagger}$ Martina Kutmon, ${ }^{\#}$ Chris T. Evelo,

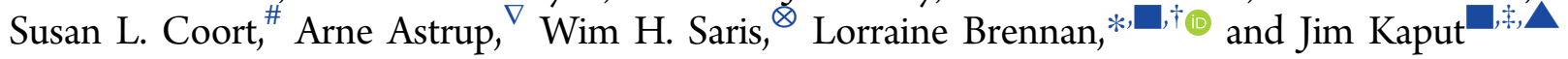

${ }^{\dagger}$ Institute of Food and Health, Food for Health Ireland, University College Dublin, Dublin 4, Republic of Ireland

${ }^{\ddagger}$ Nestlé Institute of Health Sciences, 1015 Lausanne, Switzerland

${ }^{\S}$ Leiden Academic Centre for Drug Research, Analytical BioSciences, Leiden University, 2311 EZ Leiden, The Netherlands

"The Microsoft Research - University of Trento Centre for Computational and Systems Biology (COSBI), 38068 Rovereto, Italy

${ }^{\perp}$ Nutrigenomics Research Group, UCD Conway Institute of Biomolecular and Biomedical Research and UCD Institute of Food and Health, School of Public Health, Physiotherapy and Sports Science, University College Dublin, Belfield, Dublin 4 Republic of Ireland

\#Department of Bioinformatics - BiGCaT, School of Nutrition and Translational Research in Metabolism and Maastricht Centre for Systems Biology (McCSBio), Maastricht University, 6211 LK Maastricht, The Netherlands

${ }^{\nabla}$ Department of Nutrition, Exercise and Sports, Faculty of Science, University of Copenhagen, 1165 Copenhagen, Denmark

${ }^{\otimes}$ Department of Human Biology, School of Nutrition and Translational Research in Metabolism, Maastricht University Medical Centre, 6211 LK Maastricht, The Netherlands

Supporting Information

ABSTRACT: Validated protein biomarkers are needed for assessing health trajectories, predicting and subclassifying disease, and optimizing diagnostic and therapeutic clinical decision-making. The sensitivity, specificity, accuracy, and precision of single or combinations of protein biomarkers may be altered by differences in physiological states limiting the ability to translate research results to clinically useful diagnostic tests. Aptamer based affinity assays were used to test whether low abundant serum proteins differed based on age, sex, and fat mass in a healthy population of 94 males and 102 females from the MECHE cohort. The findings were replicated in 217 healthy male and 377 healthy female participants in the DiOGenes consortium. Of the 1129 proteins in the panel, 141, 51, and 112 proteins (adjusted $p<0.1$ ) were

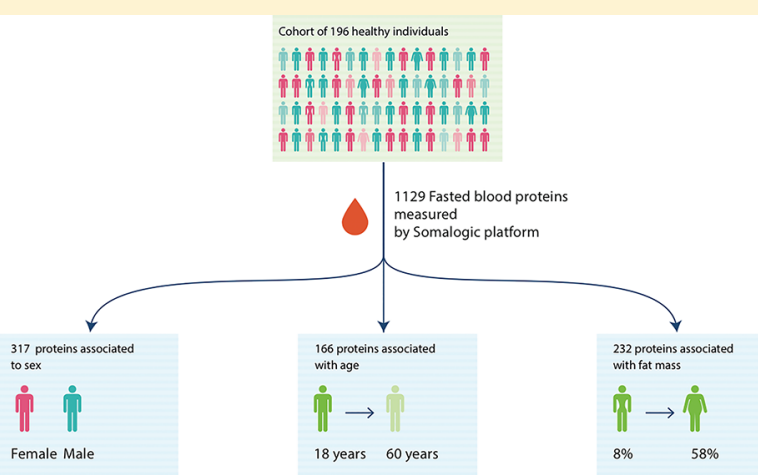
identified in the MECHE cohort and significantly replicated in DiOGenes for sexual dimorphism, age, and fat mass, respectively. Pathway analysis classified a subset of proteins from the 3 phenotypes to the complement and coagulation cascades pathways and to immune and coagulation processes. These results demonstrated that specific proteins were statistically associated with dichotomous (male vs female) and continuous phenotypes (age, fat mass), which may influence the identification and use of biomarkers of clinical utility for health diagnosis and therapeutic strategies.

KEYWORDS: proteomics, phenotype, biomarker, sex, male, female, age, fat mass, protein, pathway

\section{INTRODUCTION}

The concentrations of proteins in the blood vary dynamically in the healthy state but may also change during the trajectory toward the onset of disease. Robust technologies that accurately measure protein levels have an increasingly important role in investigating and advancing health research and clinical practice. ${ }^{1,2}$ The full promise of protein diagnostics has yet to be realized in the clinical setting. The majority of protein diagnostic tests are based on single proteins for acute conditions (e.g., myocardial infarction) or cancers. Protein signature tests consisting of multiple markers may be needed to achieve an optimal level of sensitivity and specificity for assessing complex health and disease processes. ${ }^{3}$

Variations in phenotype during aging, physiology (e.g., obesity or other physical conditions), or by sex dimorphism may independently affect protein levels making it difficult to optimize the utility of clinical diagnostics, especially in genetically and culturally diverse individuals. Many of the well-accepted risk factors for cardiometabolic disease risk have

Received: July 13, 2017

Published: September 26, 2017 
defined phenotypic cut-offs. For example, HDL cholesterol levels less than $40 \mathrm{mg} / \mathrm{dL}(1.0 \mathrm{mmol} / \mathrm{L})$ are used to assess increased risk of heart disease for men but that cutoff is $50 \mathrm{mg} /$ $\mathrm{dL}(1.3 \mathrm{mmol} / \mathrm{L})$ for women. Sex differences and other risk factors such as LDL cholesterol levels may independently increase risk of heart disease or other chronic medical conditions. ${ }^{4}$ Previous work in the field of proteomics has identified 40 low-abundant proteins which differed in serum between 12 males and 12 females $^{5}$ and more than 60 plasma proteins differed by over 2 standard deviations in 29 and 30 overweight and obese women and men, respectively. ${ }^{6}$ Age, body mass index (BMI), body fat mass, and other physiological parameters may also influence the serum proteome and therefore utility and veracity of diagnostic markers. Serum proteomic and metabolomic approaches were combined to identify circulating proteins and metabolites that differed between 5 healthy lean and 5 healthy obese men. ${ }^{7}$ That study, albeit small, established a link between the complement system and obesity and both novel and previously reported markers of alterations in body fat mass were identified. Considering age, physiological (such as, body fat mass), dietary, and other environmental variations, additional research into sex dimorphic plasma and serum protein modulations will be needed before sex specific medical and nutritional recommendations are implemented.

One of the main challenges for analyzing the blood proteome is the large dynamic range in protein concentrations. ${ }^{8} \mathrm{New}$ technologies have been developed and successfully implemented to overcome this challenge. ${ }^{9}$ Chemically modified single-stranded DNA aptamers (SOMAmers) have high specificity as affinity capture reagents for use with undiluted and diluted plasma and serum samples to quantify low and high abundant proteins. SOMAmers are used in multiplex assays similar to DNA microarrays allowing for the simultaneous analysis of over 1000 proteins in small amounts $(\sim 65 \mu \mathrm{L})$ of serum. Improvements in mass spectroscopy pipelines and analysis ${ }^{10}$ are also being made in blood proteomic analysis although these approaches require expensive equipment and expertise in the technologies.

The primary aim of the research reported here was to identify the impact of sex, age and body fat mass on the proteomic signature and replicate the findings in an independent cohort. Furthermore, the identified proteins were mapped using pathway analysis methods to provide context and a greater understanding of the biological processes that differ by phenotype. The results of this study provide a foundational understanding of the effect of these 3 phenotypic variables on protein markers.

\section{METHODS}

\section{Study Population}

The research described here extended the Metabolic Challenge (MECHE) study which is part of a national research program by the Joint Irish Nutrigenomics Organisation. ${ }^{11}$ Briefly, the MECHE study enrolled 214 participants aged 18-60 y who underwent an oral glucose tolerance test (OGTT) and/or oral lipid tolerance test (OLTT). Clinical measures, body composition, and dietary habits were assessed in the fasted state (baseline) and at multiple time points following each challenge. ${ }^{11}$ Demographic parameters obtained at baseline were used for analysis. Height was obtained using a wall mounted Harpenden stadiometer (Holtain Limited, UK) and weight was measured using a calibrated beam balance platform scale (SECA 888, Germany). Total fat mass was determined using DXA scanning (Lunar iDXA, GE Healthcare, UK). Individuals were informed about the purpose of the study and the experimental procedures, prior to giving written consent. Good health was defined as the absence of any known chronic or infectious disease and this was verified by a number of fasting blood tests. Individuals with a BMI below $18.5 \mathrm{~kg} / \mathrm{m}^{2}$, a low blood hemoglobin concentration $(<12 \mathrm{~g} / \mathrm{dL})$, an elevated fasting plasma glucose $(\geq 7 \mathrm{mM})$, an elevated cholesterol concentration $(>7.5 \mathrm{mM})$, an elevated triglyceride concentration $(>3.8 \mathrm{mM})$ and elevated enzyme indicators of liver or kidney function, any of which warranted pharmaceutical intervention, were excluded. Details of the study have been published elsewhere. ${ }^{11-13}$ The study was registered at clinicaltrials.gov under NCT01172951. Ethical approval was obtained from the Research Ethics Committee at University College Dublin (LS-08-43-Gibney-Ryan) and the study was performed according to the Declaration of Helsinki. For the present study, participants from the MECHE study who had proteomic data were included $(n=200)$ (Table 1$)$.

Table 1. Clinical Characteristics of Study Participants ${ }^{a}$

$\begin{array}{lll} & \text { MECHE }(n=196) & \text { DiOGenes }(n=594) \\ \text { Sex }(\mathrm{m} / \mathrm{f}) & 94 / 102 & 217 / 377 \\ \text { Age }(\mathrm{y}) & 31 \pm 10^{b} & 42 \pm 6^{c} \\ \text { Weight }(\mathrm{kg}) & 74.42 \pm 15.99 & 99.87 \pm 17.8 \\ \text { BMI }\left(\mathrm{kg} / \mathrm{m}^{2}\right) & 24.7 \pm 4.8 & 34.2 \pm 4.8 \\ \text { WHR } & 0.84 \pm 0.1 & - \\ \text { BP SYS }(\mathrm{mm} / \mathrm{Hg}) & 122.93 \pm 12.37 & - \\ \text { BP DIA }(\mathrm{mm} / \mathrm{Hg}) & 73.69 \pm 10.52 & - \\ \text { Glucose }(\mathrm{mmol} / \mathrm{L}) & 5.21 \pm 0.58 & - \\ \text { HDL-c }(\mathrm{mmol} / \mathrm{L}) & 1.35 \pm 0.35 & 1.2 \pm 0.33 \\ \text { TAG }(\mathrm{mmol} / \mathrm{L}) & 1.04 \pm 0.62 & 1.37 \pm 0.65 \\ \text { Insulin }(\mu \mathrm{IU} / \mathrm{mL}) & 8.71 \pm 6.93 & - \\ \text { HOMA-IR } & 1.87 \pm 1.51 & 3.16 \pm 2.56 \\ \text { Body fat } \% & 25.76 \pm 10.92 & - \\ \text { DEXA fat mass }(\mathrm{kg}) & 28.28 \pm 9.72 & 39.72 \pm 11.1\end{array}$

${ }^{a}$ Data are presented as means \pm standard deviation (SD); BMI: body mass index; WHR: waist to hip ratio; HDL-c: high-density lipoprotein cholesterol; TAG: triacylglycerol; HOMA: homeostasis model assessment. ${ }^{b} 18-60$ y. ${ }^{c} 23-58 \mathrm{y}$.

\section{Proteomics Analysis}

1129 proteins were quantified in fasting (at least $12 \mathrm{~h}$ ) serum samples of 200 MECHE participants using the proteomic platform SOMAmer (Slow Off-rate Modified Aptamer) as previously described. ${ }^{9}$ Data set is available upon request. This technology has a dynamic range of more than 8 logs, allowing quantification of both low and high abundant proteins which might otherwise be missed. Preprocessing of the proteomic data included log transformation of the abundance of each protein. Principal component analysis (PCA) did not reveal any significant batch effect across the proteins analyzed. PCA identified four individuals as outliers whose data were removed. Therefore, the final proteomic data set included 196 individuals and 1129 proteins. Proteins measured by SOMAmers are found in the blood as secreted (431), external membrane origin (275), and intracellular proteins (423). Proteins are often shed from membranes by proteolytical cleavage and intracellular proteins may be released from cells as a part of normal or abnormal physiological cell turnover. 
Table 2. Proteomics Results Depict Sexual Dimorphism: Proteins Higher in Males ${ }^{a}$

\begin{tabular}{|c|c|c|c|c|c|}
\hline full protein name & UniProt ID & protein & OPLS-DA score ${ }^{b}$ & $\mathrm{p}$ (corr) & cellular location \\
\hline Myoglobin & P02144 & MB & 0.118 & 0.613 & Exosome \\
\hline Matrix metalloproteinase 3 (Stromelysin 1 ) & P08254 & MMP3 & 0.110 & 0.574 & Secreted \\
\hline Bone morphogenetic protein-1 & P13497 & BMP-1 & 0.105 & 0.549 & Secreted \\
\hline Serum amyloid $\mathrm{P}$ & P02743 & SAP & 0.100 & 0.522 & Secreted \\
\hline Tissue factor pathway inhibitor & P10646 & TFPI & 0.099 & 0.516 & Secreted \\
\hline Protein $S$ & P07225 & Protein $S$ & 0.096 & 0.501 & Secreted \\
\hline Ficolin-3 & O75636 & Ficolin-3 & 0.094 & 0.491 & Secreted \\
\hline Interleukin-1 receptor-like 1 (ST2) Interleukin-1 receptor 4 & Q01638 & IL-1 R4 & 0.093 & 0.483 & Secreted \\
\hline LEAP-1 (Hepcidin) & P81172 & LEAP-1 & 0.090 & 0.470 & Secreted \\
\hline Liver-expressed chemokine HCC-4 & 015467 & HCC-4 & 0.088 & 0.459 & Secreted \\
\hline
\end{tabular}

${ }^{a}$ Data presented as first 10 significant proteins out of 173 total in males using OPLS-DA with a 0.15 cutoff. ${ }^{b}$ Describes the direction of the difference in males vs females.

Table 3. Proteomics Results Depict Sexual Dimorphism: Proteins Higher in Females ${ }^{a}$

\begin{tabular}{|c|c|c|c|c|c|}
\hline full protein name & UniProt ID & protein & OPLS-DA score ${ }^{c}$ & $\mathrm{p}$ (corr) & cellular location \\
\hline Sex hormone-binding globulin & P04278 & SHBG & -0.102 & -0.531 & Secreted \\
\hline Leptin (OB) & P41159 & Leptin & -0.098 & -0.513 & Secreted \\
\hline Thyroxine-binding globulin & P05543 & Thyroxine Binding Globulin & -0.097 & -0.507 & Secreted \\
\hline Adiponectin & Q15848 & Adiponectin & -0.089 & -0.466 & Secreted \\
\hline Angiotensinogen & P01019 & Angiotensinogen & -0.079 & -0.414 & Secreted \\
\hline Fetuin B & Q9UGM5 & FETUB & -0.073 & -0.381 & Secreted \\
\hline Immunoglobulin $\mathrm{M}$ & P01871 & $\operatorname{IgM}$ & -0.072 & -0.378 & Secreted \\
\hline Trefoil factor 3-Intestinal trefoil factor (hITF) & Q07654 & TFF3 & -0.071 & -0.369 & Secreted \\
\hline Limbic system-associated membrane protein (LAMP) & Q13449 & LSAMP & -0.069 & -0.362 & Membrane \\
\hline Collectin Placenta $1^{b}$ & Q5KU26 & COLEC12 & -0.067 & -0.351 & Membrane \\
\hline
\end{tabular}

${ }^{a}$ Data presented as first 10 significant proteins out of 144 total in females using OPLS-DA with a 0.15 cutoff. ${ }^{b}$ Only protein not replicated in DiOGenes data set. ${ }^{c}$ Describes the direction of the difference in males vs females.

\section{Replication Cohort}

Participants were recruited from 8 cities in 8 European counties that were healthy, overweight/obese with a BMI between 27 and $45 \mathrm{~kg} / \mathrm{m}^{2}$ and aged $<65 \mathrm{y}$. Informed consent was obtained from all participants and the study was approved by the local Medical Ethical Committees in the respective research centers, in accordance with the Helsinki Declaration. ${ }^{14}$ The DiOGenes intervention study was registered on Clingov (NCT00390637). The DiOGenes cohort were selected as a suitable replication cohort for this analysis due to the availability of SOMAlogic data and a large sample size. SOMAlogic proteomic data were analyzed in serum of 594 participants: 377 females and 217 males of the DiOGenes consortium, age 16-63 y, mean BMI $34 \pm 4.8 \mathrm{~kg} / \mathrm{m}^{2}$ (0 individuals with BMI $<25,122$ individuals with BMI 25-30, and 472 individuals with BMI > 30 (15).

\section{Statistical Methodology}

Analysis for study population characteristics was carried out using IBM SPSS Statistics 20. Data are expressed as means \pm standard deviation. Multivariate statistical analysis was performed using Simca-P+ software (version 14.0; Umetrics, Umea, Sweden). Prior to data analyses the MECHE data set was scaled using UV scaling. PCA and PLS-DA was carried out to explore differences in protein levels between males and females. Orthogonal partial last-squares discriminant analysis (OPLS-DA) was performed which improves interpretation and separation between classes on a scores plot by filtering unwanted variation. A S-plot was generated from which potential proteins of interest were extracted. A value for $p$ (corr) $>0.15$ was used to select proteins that differed significantly between males and females to enhance identification of pathways.
Robust regression ( $\mathrm{R}$ package limma) ${ }^{16}$ was used to identify proteins that were significantly associated with either age or total body fat measured by DEXA (fat mass in $\mathrm{kg}$ ). Robust regression was chosen over linear regression since it is less sensitive to outliers. Proteins levels were first transformed to the residuals from a linear regression on sex to correct for this covariate. The threshold of significance of Benjamini Hochberg $(\mathrm{BH})$ adjusted $p$-values was 0.1 . Baseline serum samples from DiOGenes were analyzed to test replication of the effect of sex, age, and fat mass on protein levels. Robust regressions corrected for the collection center and sex, when analyzing age and fat mass.

\section{Pathway Annotation}

Pathway over-representation analysis was performed with the human pathway collection from WikiPathways (curated collection with 276 pathways downloaded on 26 January 2016) using PathVisio (version 3.2.4). ${ }^{17}$ Permuted $p$-value is calculated by performing a permutation test. The data is permuted 1000 times and a rank is calculated of the actual $\mathrm{Z}$ score compared to the permuted $\mathrm{Z}$ Scores. The $\mathrm{Z}$ scores are calculated based on the changed proteins in a pathway out of the total proteins in the pathway that have been measured in the uploaded data set. Pathways with a Z-score of $>1.96$ and a permuted $p$-value $<0.05$ are considered important. Functional pathway enrichment analyses were also performed with KEGG and Reactome databases with the R packages HTSAnalyzer ${ }^{18}$ and ReactomePA, ${ }^{19}$ respectively. The analyses were conducted with all ENTREZ proteins/genes as background and with an adjusted $p$-value threshold of 0.05. Pathway analyses were conducted only with proteins found to vary significantly in the same direction in both cohorts. 


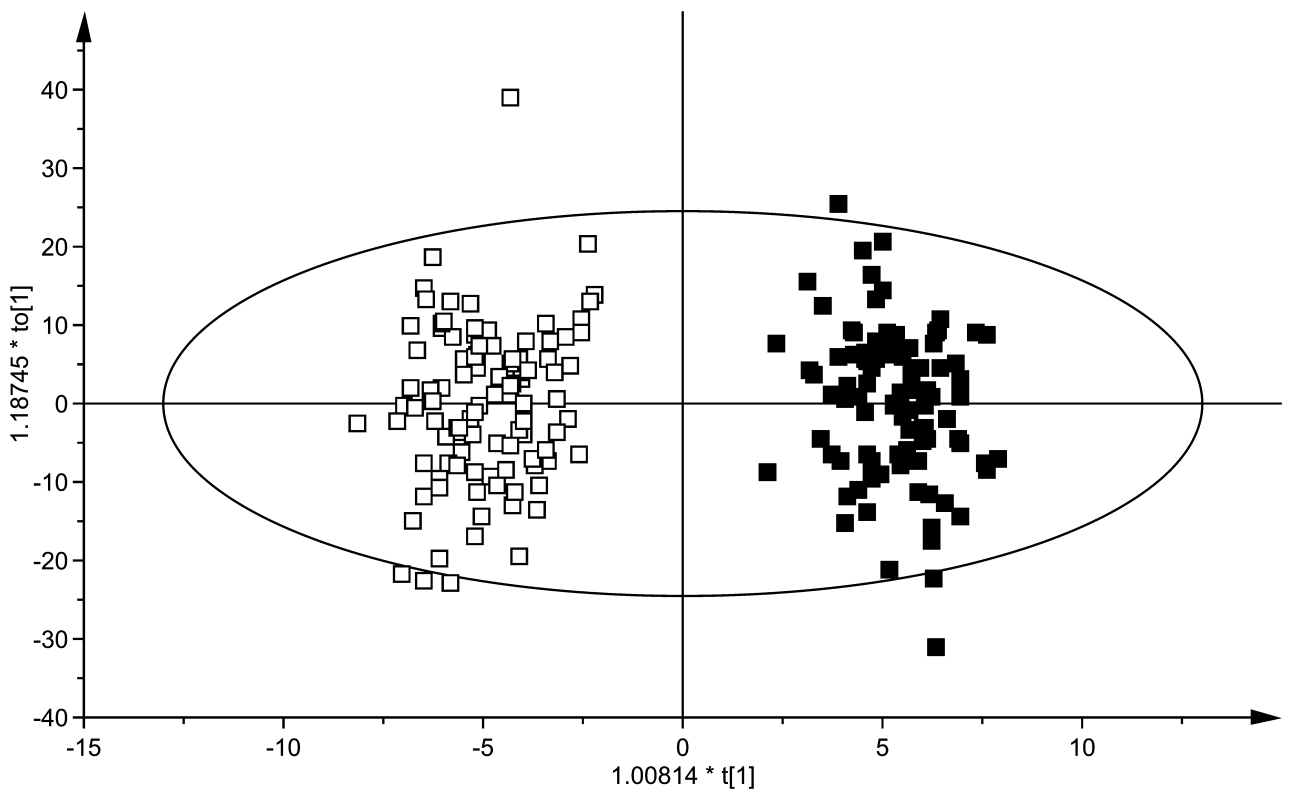

Figure 1. OPLS-DA of males vs females derived from proteomic data of MECHE participants $(n=196)$. ( $\square)$ Males, $(\square)$ Females, $R^{2} Y=0.945 ; Q^{2}=$ 0.765 .

\section{RESULTS AND DISCUSSION}

\section{Sexual Dimorphism}

The 317 differentially expressed proteins between male and female in the MECHE cohort account for $28 \%$ of the total proteins analyzed (Table 2 and 3, Figure 1). From there 141 proteins were replicated in the DiOGenes cohort (Table S5a and $\mathrm{S} 5 \mathrm{~b})$. The top 10 most statistically significant overexpressed proteins for each sex were compared for known physiological functions and associations with sex hormones, metabolic disease, diet, and previously characterized sex dimorphism (Table S1 and S2).

The 8 most significant secreted proteins elevated in females have known associations with sex hormone metabolism (SHBG, leptin, thyroxin-binding globulin, adiponectin, angiotensinogen, fetuin $\mathrm{B}$, immunoglobulin $\mathrm{M}$, trefoil factor 3 ) (Table 3). ${ }^{20-25}$ Each of these proteins is involved in at least one diet related metabolic disease (except immunoglobulin $\mathrm{M}$ ) (Table S1). These proteins were affected by or affect glucose and insulin metabolism (SHBG, leptin, adiponectin, fetuin B, trefoil factor 3), metabolic rate (thyroxin binding globulin), and dietary carbohydrate intake (SHBG, leptin, adiponectin), and salt sensitive hypertension (angiotensinogen). ${ }^{21,22,26-30}$ Increased immunoglobulin $\mathrm{M}$ expression has been associated with gluten and dietary protein intakes. ${ }^{31,32}$ Recent studies suggest SHBG, adiponectin, angiotensinogen, and fetuin B may be involved in diabetes development. ${ }^{28,33-35}$ The cellmembrane located immune proteins, LAMP, and collectin placenta 1 were upregulated in females. These proteins stimulate neural growth and provide host defense with no previously described difference by sex or metabolic disease associations. $^{36,37}$ Of note, collectin placenta 1 is the only protein within this group that was not replicated in the DiOGenes data.

Nine of the top 10 most significant proteins more abundant in males are secreted (exception is myoglobin located in the exosome, Table 2). Of these 10, several are associated with sex hormone metabolism (myoglobin, matrix metalloproteinase 3, serum amyloid $\mathrm{P}$, tissue factor pathway inhibitor, protein $\mathrm{S}$, interleukin 1 receptor like 1 , LEAP). ${ }^{38-46}$ These top 10 proteins function in connective tissue development and growth, amyloid deposit development, blood coagulation, inflammation modulation, antimicrobial immunity and iron metabolism, as well as, immune cell migration and adhesiveness. These proteins are involved in processes contributing to metabolic diseases, specifically myocardial infarction (myoglobin), cardiovascular disease (matrix metalloproteinase), atherosclerosis (serum amyloid $\mathrm{P}$, tissue factor pathway inhibitor, protein $\mathrm{S}$ ), diabetes (ficolin-3), and iron overload (LEAP-1). ${ }^{47-52}$ Certain nutrients alter the abundances of some of these proteins: iron (myoglobin, LEAP), lipids (myoglobin), monounsaturated fatty acids, and n-3 PUFA (tissue factor pathway inhibitor), vitamin $\mathrm{K}$ (protein S), and vitamin A (LEAP) although the effect of diet was not analyzed in the MECHE cohort. The liver expressed chemokine (HCC-4) may be induced by total fat and calorie intake. ${ }^{53-60}$ All 10 significant proteins found in MECHE were replicated in the same direction with robust regression in the DiOGenes data (Table S5a).

Interpreting the role of a protein by its activity, association to a disease process, or to an individual provides information on physiological states. However, our results suggest a more holistic difference between males and females since the coagulation pathway cross-talks with and cross-regulates the immune system to maintain homeostasis. ${ }^{61}$ Serpin Family D Member 1, al-antitrypsin and plasminogen mapped to the complement and coagulation cascades pathway (see Figure 3) in females. The same pathway was identified in males but through different proteins (tissue factor pathway inhibitor, thrombin activatable fibrinolysis inhibitor, plasminogen activator, serpin family A member 5, serpin family $\mathrm{C}$ member 1 and Protein S). Tissue factor pathway inhibitor is present in free and lipoprotein-associated forms ${ }^{62}$ while protein $S$ is more frequently ( $60 \%$ of total) bound to $\mathrm{C} 4 \mathrm{~B}$ which abolishes its anticoagulant properties. ${ }^{63}$ Bound and free Protein $S$ were more abundant in males compared to females. ${ }^{64}$ This protein also is involved in phagocytosis of apoptotic cells. ${ }^{65}$ Others studies identified Serpin Family D Member 1, Serpin Family C Member 1, Serpin Family A Member 1 and protein S among 27 

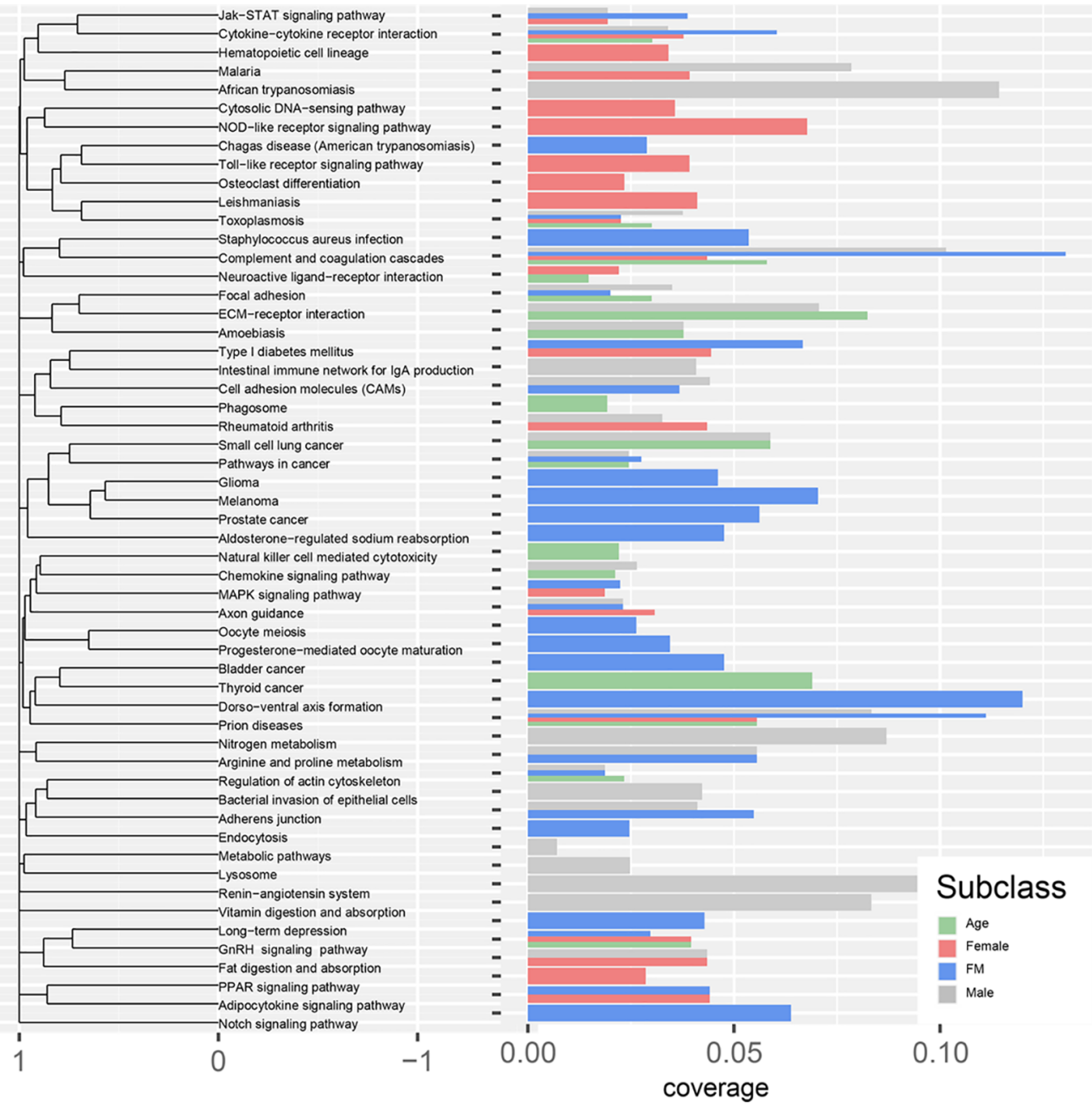

Figure 2. Overview of KEGG pathway enrichment. Bar graph displaying KEGG pathway enrichments by classes (proteins significant for male, female, age and fat mass). The size of the bar graph represent the coverage of the pathway (number significant proteins in the pathway/number of total proteins in the pathway). The dendrogram groups similar pathways (pathways that include similar genes).

\section{Table 4. Proteomics Results Significantly Associated with Age ${ }^{a}$}

\begin{tabular}{|c|c|c|c|c|c|}
\hline full protein name & UniProt ID & protein & $p$-value & adj $p$-value & cellular location \\
\hline Interleukin 1 receptor like 2 & Q9HB29 & IL1RL2 & $1.85 \times 10^{-13}$ & $2.09 \times 10^{-10}$ & Membrane \\
\hline \multirow[t]{2}{*}{ alpha polypeptide-follicle stimulating hormone beta subunit } & P01215 & CGA & $1.12 \times 10^{-11}$ & $6.34 \times 10^{-09}$ & Secreted \\
\hline & P01225 & FSHB & & & \\
\hline Metallopeptidase with thrombospondin type 1 motif 5 & Q9UNA0 & ADAMTS5 & $1.41 \times 10^{-10}$ & $5.29 \times 10^{-08}$ & Secreted \\
\hline Chitinase 1 & Q13231 & CHIT1 & $2.08 \times 10^{-10}$ & $5.88 \times 10^{-08}$ & Secreted \\
\hline Agouti related neuropeptide & 000253 & AGRP & $4.51 \times 10^{-10}$ & $1.02 \times 10^{-07}$ & Secreted \\
\hline Osteomodulin ${ }^{b}$ & Q99983 & $\mathrm{OMD}$ & $6.89 \times 10^{-10}$ & $1.30 \times 10^{-07}$ & Secreted \\
\hline Ret proto-oncogene 2 & P07949 & RET & $2.85 \times 10^{-09}$ & $4.60 \times 10^{-07}$ & Membrane \\
\hline Cell adhesion associated, oncogene regulated & Q4KMG0 & $\mathrm{CDON}$ & $1.32 \times 10^{-07}$ & $1.86 \times 10^{-05}$ & Membrane \\
\hline Insulin like growth factor binding protein 3 & P17936 & IGFBP3 & $1.83 \times 10^{-07}$ & $2.29 \times 10^{-05}$ & Secreted \\
\hline Insulin like growth factor binding protein 5 & P24593 & IGFBP5 & $2.04 \times 10^{-07}$ & $2.30 \times 10^{-05}$ & Secreted \\
\hline
\end{tabular}

${ }^{a}$ Data presented as top 10 significant proteins out of 166 total using robust regression with correlations calculated using residuals following correction for sex. ${ }^{b}$ Only protein not replicated in DiOGenes data set.

significant proteins that differed in the complement and coagulation cascades between males and females. ${ }^{6}$ Toll- like receptors, immune- and adipo-cytokine proteins were more abundant in females. These proteins mapped to pathways (Figures 2, Figure S1, Table 6, Tables S6-S8) previously identified as belonging to the inflammasome, ${ }^{66}$ a system of interacting networks regulating acute and chronic inflammatory conditions. The individual proteins mapped to these pathways (e.g., members of the interleukin family) have been linked with diseases associated with chronic inflammation in (for example) obesity and $\mathrm{T} 2 \mathrm{DM},{ }^{65}$ the pathogenesis for which differs between men and women. ${ }^{67,68}$ This connected complementimmune system may result from and contribute to metabolic differences of sex dimorphism. How these related systems are 
Table 5. Proteomics Results Significantly Associated with Fat Mass ${ }^{a}$

\begin{tabular}{|c|c|c|c|c|c|}
\hline full protein name & UniProt ID & protein & $p$-value & adj $p$-value & cellular location \\
\hline Leptin & P41159 & Leptin & $1.57 \times 10^{-18}$ & $1.78 \times 10^{-15}$ & Secreted \\
\hline Tissue-type plasminogen activator & P00750 & PLAT & $2.92 \times 10^{-13}$ & $1.32 \times 10^{-10}$ & Secreted \\
\hline Insulin-like growth factor-binding protein 1 & P08833 & IGFBP1 & $3.51 \times 10^{-13}$ & $1.32 \times 10^{-10}$ & Secreted \\
\hline Trefoil factor 3 & Q07654 & TFF3 & $2.09 \times 10^{-12}$ & $5.90 \times 10^{-10}$ & Secreted \\
\hline Sex hormone-binding globulin & P04278 & SHBG & $7.32 \times 10^{-11}$ & $1.65 \times 10^{-8}$ & Secreted \\
\hline Matrix metalloproteinase 2 & P08253 & MMP2 & $3.56 \times 10^{-10}$ & $6.70 \times 10^{-8}$ & Secreted \\
\hline WAP, kazal, immunoglobulin, kunitz and NTR domain-containing protein 2 & Q8TEU8 & WFIKKN2 & $4.80 \times 10^{-10}$ & $7.74 \times 10^{-8}$ & Secreted \\
\hline Complement C 1s & P09871 & $\mathrm{C} 1 \mathrm{~S}$ & $9.65 \times 10^{-9}$ & $1.36 \times 10^{-6}$ & Exosome \\
\hline Hemojuvelin & Q6ZVN8 & HFE2 & $2.16 \times 10^{-8}$ & $2.71 \times 10^{-6}$ & Membrane \\
\hline Transferrin & P02787 & $\mathrm{TF}$ & $2.44 \times 10^{-8}$ & $2.75 \times 10^{-6}$ & Secreted \\
\hline
\end{tabular}

${ }^{a}$ Data presented as top 10 significant proteins out of 233 total using robust regression with correlations calculated using residuals following correction for sex. All proteins replicated with DiOGenes data set.

Table 6. Overview of Pathways Related to Sex, Age, and Fat Mass Using WikiPathways ${ }^{a}$

\begin{tabular}{|c|c|c|c|c|c|c|}
\hline & pathway & positive & measured & Z score & $P$ & ID \\
\hline \multirow[t]{6}{*}{ Males } & Complement and Coagulation Cascades & 7 & 40 & 2.27 & 0.039 & WP558 \\
\hline & Selenium Micronutrient Network & 7 & 27 & 3.49 & 0.003 & WP15 \\
\hline & Vitamin B12 Metabolism & 7 & 24 & 3.88 & 0.002 & WP1533 \\
\hline & Folate Metabolism & 6 & 26 & 2.88 & 0.011 & WP176 \\
\hline & Statin Pathway & 3 & 4 & 4.95 & 0.001 & WP430 \\
\hline & Urea cycle and metabolism of amino groups & 3 & 4 & 4.95 & 0.001 & WP497 \\
\hline \multirow[t]{4}{*}{ Females } & Adipogenesis & 5 & 23 & 4.05 & $<0.01$ & WP236 \\
\hline & Aryl Hydrocarbon Receptor & 3 & 19 & 2.41 & 0.032 & WP2586 \\
\hline & FAS pathway and Stress induction of HSP regulation & 3 & 15 & 2.93 & 0.021 & WP314 \\
\hline & Myometrial Relaxation and Contraction Pathways & 3 & 22 & 2.1 & 0.031 & WP289 \\
\hline \multirow[t]{2}{*}{ Aging } & Complement and Coagulation Cascades & 4 & 40 & 2.01 & 0.044 & WP558 \\
\hline & Senescence and Autophagy in Cancer & 4 & 39 & 2.07 & 0.047 & WP615 \\
\hline \multirow[t]{10}{*}{ Fat mass } & Spinal cord injury & 8 & 47 & 1.78 & 0.052 & WP2431 \\
\hline & Complement and Coagulation Cascades & 7 & 40 & 1.74 & 0.053 & WP558 \\
\hline & Adipogenesis & 6 & 23 & 2.72 & 0.006 & WP236 \\
\hline & Cardiac Progenitor Differentiation & 5 & 15 & 3.15 & 0.008 & WP2406 \\
\hline & Neural Crest Differentiation & 5 & 18 & 2.65 & 0.017 & WP2064 \\
\hline & Complement Activation & 4 & 17 & 1.97 & 0.038 & WP545 \\
\hline & AMPK signaling & 3 & 12 & 1.82 & 0.049 & WP1403 \\
\hline & Differentiation of white and brown adipocyte & 3 & 3 & 5.33 & $<0.01$ & WP2895 \\
\hline & Notch Signaling Pathway & 3 & 7 & 3 & 0.013 & WP268 \\
\hline & NOTCH1 regulation of human endothelial cell calcification & 3 & 10 & 2.2 & 0.039 & WP3413 \\
\hline
\end{tabular}

${ }^{a}$ Pathways obtained from pathway statistics using PathVisio software, using the curated WikiPathways directory. Pathways with a Z-Score of $>1.96$, a $p$-value of $<0.05$ and who have 3 or more proteins differentially expressed are considered important. $p$-value is permuted. Sorted by number of differentially expressed proteins in pathway.

regulated will require more comprehensive analysis of components of these pathways in future studies.

Age

Regression analysis revealed 167 proteins (15\% of 1129 proteins) significantly associated (adjusted $p$-value $<0.1$ ) with age (range: $20-60 \mathrm{y}$ ). Fifty-one of these protein-age associations were replicated in the DiOGenes data (Table $\mathrm{S} 5 \mathrm{c}$ ). Coefficients of the regression for age can also be found in Table S5c. The top 10 proteins associated with age were IL1RL2, FSHB, ADMTS5, CHIT1 (all positively correlated with age) and AGRP, OMD, RET, CDON, IGFBP3 and IGFBP5 (negatively correlated with age) (see Table 4), however OMD was not significantly associated in DiOGenes. The levels of the majority of these proteins, with the exception of IL1RL2 and CDON, were previously associated with age. ${ }^{69-75}$ The identified proteins are involved in diseases and suboptimal states of health in relation to aging including (i) inflammation (IL1RL2, CHIT1), ${ }^{74,76}$ (ii) arthritis (ADAMTS5,
IGFBP3), ${ }^{77,78}$ (iii) vertebral fractures (IGFBP3) ${ }^{79}$ (iv) bone metabolism (IGFBP5,AGRP,OMD), ${ }^{80-82}(\mathrm{v})$ weight homeostasis (AGRP,CDON), ${ }^{83,84}$ (vi) lean body mass (IGFBP3), ${ }^{85}$ (vii) cancer development (RET,CDON $)^{86,87}$ and prevention (IGFBP3, IGFBP5), ${ }^{88,89}$ and (viii) muscle metabolism (IGFBP3, IGFBP5, CDON). ${ }^{90,91}$ Levels of FSHB and AGRP were positively influenced by caloric restriction and a high-fat diet, while IGFBP3 was impacted by supplementing the diet with n-3 PUFA. ${ }^{92-94}$

Annotation of the MECHE proteins statistically significant in the DiOGenes cohort identified a number of associated pathways (Figure 2, Figure S1, Table 6, Tables S6-S8). Four proteins associated with aging emerged in the complement and coagulation cascade pathway, of which SERPING1 (cl esterase inhibitor) was specific to aging. Increases in $\mathrm{C} 1$ esterase inhibitor are observed during inflammation. ${ }^{95}$ All of these proteins with the exception of CCL21 were positively associated with increased age. The chemokine pattern found 


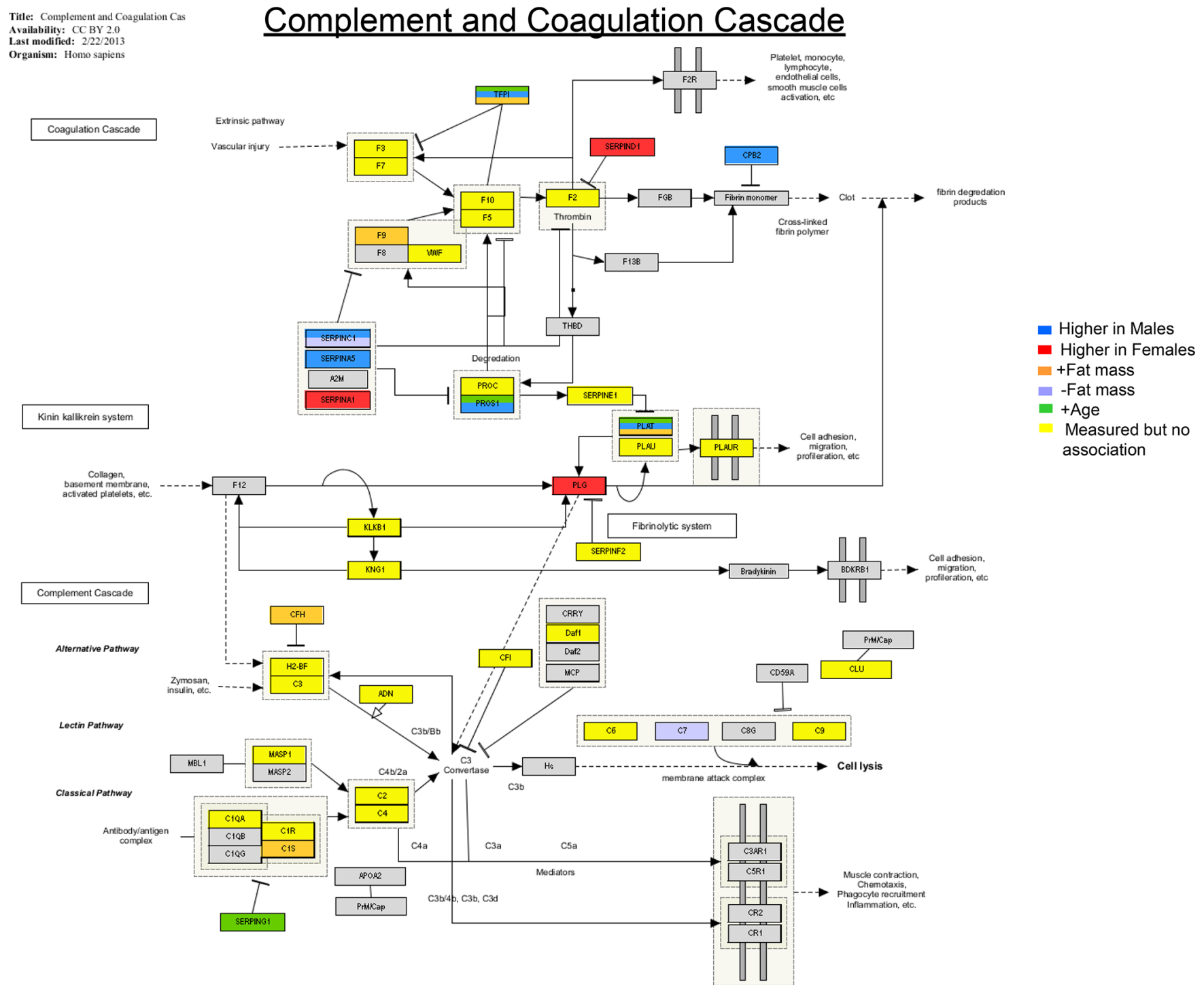

Figure 3. Complement and coagulation cascades pathway obtained from WikiPathways displaying proteins differentially expressed across sex, age, and fat mass phenotypes. Females, Males, + Fat mass $=$ upregulated, - Fat mass $=$ downregulated, + Age $=$ upregulated; all proteins upregulated in males and females.

in this study (CCL21 lower and other CCL's higher) was consistent with other studies showing increased expression of CCL27 in senescent cells, ${ }^{96}$ levels of CCL11 and CCL7 in aged animals or humans, ${ }^{97}$ and decreased levels of CCL2 $1 .{ }^{98}$ Further pathways of interest were identified through KEGG and Reactome (Tables S6-S7). Collectively, these proteins and the pathways in which they act are processes consistent with inflammation, the interconnected processes that result from lifelong insults to the immune system resulting in chronic lowgrade inflammation and immunosenescence. ${ }^{99}$

\section{Fat Mass}

Regression analysis identified $21 \%$ of SOMAscan proteins significantly associated (adjusted $p$-value $<0.1$ ) with body fat mass (range: $8-58.2 \mathrm{~kg}$ ). Of these 232 proteins, 112 were replicated at an adjusted $p$-value $<0.1$ in the DiOGenes cohort, with coefficients of regression displayed in Table S5d. The top 10 proteins associated with body fat mass are LEP, PLAT and C1S (all positively correlated with fat mass) and IGFBP1, TFF3, SHBG, MMP2, WFIKKN2, HFE2 and TF (negatively correlated with fat mass) (Table 5). All 10 proteins were replicated in the DiOGenes cohort. The physiologic functions of these top proteins include inflammation, glucose metabolism, defense response, blood coagulation, regulation of cell growth, along with angiogenesis and iron homeostasis (Table S4). Leptin was strongly associated with fat mass ${ }^{100,101}$ and elevated in females, consistent with its known role in regulation of body weight and energy balance. ${ }^{102,103}$

Increased BMI and fat mass are known risk factors for diseases such as metabolic syndrome and cardiovascular disease (CVD). Three proteins associated with fat mass in the MECHE/DiOGenes cohorts (tPA, IGFBP-1, and TFF3) have been associated with metabolic conditions. High levels of tPA antigen independently predicted cardiovascular events both in a healthy population and in individuals with prevalent coronary disease. ${ }^{104}$ Elevated plasma tPA antigens were associated with insulin resistance, T2D, and obesity. Decreased abundance of plasma tPA (approximately 29\%) was observed following a 12 week energy restricted diet in overweight women with metabolic syndrome. ${ }^{105}$ Insulin like growth factor binding protein 1 (IGFBP-1) is negatively associated with fat mass in 
the MECHE/DiOGenes cohorts. Lower levels of IGFBP-1 at baseline was associated with the combination of increased percentage body fat and plasma insulin levels. ${ }^{106}$ Trefoil factor 3 (TFF3) was negatively associated with fat mass but positively associated with female sex. Increased levels of TFF3 were observed to improve glucose tolerance in a diet-induced obesity mouse model, which supports previous reports that TFF3 plays a role in energy metabolism. ${ }^{107}$

The 112 differentially abundant proteins associated with fat mass were mapped to KEGG, WikiPathways and Reactome pathways (Figure 2, Figure S1, Table 6, Tables S6-S8). Seven proteins significantly associated with fat mass mapped to the complement and coagulation cascade pathway (Figure 3). The complement and coagulation cascade pathway is associated with chronic disease risk. ${ }^{108}$ In this pathway, abundances of TFPI, coagulation factor IX, tPA, Factor $\mathrm{H}$ and $\mathrm{C}$ 1s were higher while antithrombin III and C7 were less abundant as fat mass increased. Although not directly tested in this study, enzymatic activity of thrombin would be maintained in conditions of decreased levels of antithrombin III with the result that coagulation would be increased. The association between increased coagulation factor IX, which is also inhibited by antithrombin III, and increased fat mass found in the MECHE/DiOGenes cohorts is consistent with more active coagulation processes. Evidence from cell culture demonstrated that a subset of proteins expressed in the complement pathway were altered in adipose cells from insulin resistant humans and in animal models of obesity. ${ }^{109}$ These proteins associated with fat mass and the pathways to which they belong suggest a link between insulin resistance, T2D, and coagulation processes.

Fifteen proteins, including adiponectin, insulin, and leptin mapped to the Reactome development biology pathway (Figure S1, Table S7) and to KEGG cytokine-cytokine receptor interactions (Figure 2, Table S6). Eleven other proteins, which included ECM proteins (e.g., NCAM1, MMP2, CHL1 negative associations with FM) and growth factors (EGFR, FGFR1, negative associations with FM) were also assigned to the axon guidance pathway, a participant in Reactome's developmental biology pathway. The axon guidance pathway was identified in a transcriptomic analysis of fatty hearts in miniature pigs fed a high energy diet ${ }^{110}$ suggesting that dysregulation of these genes may not be specific to neuronal tissues. Decreased levels of axon guidance proteins (e.g., UNC5D, RGMB CHL1) may alter neuro-adipose junctions involved in leptin regulation. ${ }^{111}$ The mapping of individual proteins to multiple pathways also identified potential processes associated with increased fat mass. For example, NOTCH1 was found in 11 of the 33 significantly enriched Reactome pathways. NOTCH1 was inversely associated with fat mass in the present study. Decreases in levels of endothelial NOTCH1 may be a risk factor for vascular inflammation and promotion of diet-induced atherosclerosis. ${ }^{112}$ Therefore, examination of pathways related to fat mass provides a platform for further investigation of associated biological processes.

\section{Phenotypic Variables Have an Impact on Protein Levels}

Examining the impact of phenotypic variables revealed the importance of considering sex, age and fat mass in proteomics studies. Aptamer based binding assays were used to quantify low abundant serum proteins at baseline in healthy participants of the MECHE ${ }^{11}$ and DiOGenes ${ }^{15}$ cohorts based on sex, body fat, and age. Forty four percent of sex proteins (51\% male, 35\% female), $31 \%$ age proteins and $49 \%$ fat mass proteins identified as significant in the MECHE cohort were replicated in the DiOGenes cohort. The differences in replicated proteins for each phenotype group likely reflects known differences between the two cohorts. DiOGenes participants were older in age (41.6 \pm 6.1 vs $31 \pm 10 \mathrm{y}$ in MECHE) with a higher BMI $(34.2 \pm 4.8$ vs $24.7 \pm 4.8 \mathrm{~kg} / \mathrm{m}^{2}$ in MECHE) and more body fat $(39.7 \pm$ 11.1 vs $25.76 \pm 10.9 \mathrm{~kg}$ in MECHE) (Table 1). The difference in these parameters is considered a strength since the same proteins were significant in a slightly older and more obese cohort, which extends the use of these proteins in studies of individuals with wider age and BMI ranges. Histogram plots of age and sex for both cohorts are in Figures $\mathrm{S} 2 \mathrm{a}-\mathrm{f}$. Two proteins overlapped all 3 phenotype groups, 6 proteins between age and sex, 30 proteins between sex and fat mass and 4 proteins between age and fat mass (Figure S3). Scatterplots of proteins related to age and fat mass respectively can be found in Figure S6 and Figure S7. The present results highlight the need for including phenotypic parameters in proteomics studies and make a case for the development of phenotypic specific cut offs. Differences in sex, age and fat mass may independently induce quantitative changes in the proteins thought to be specific for a biological process or disease phenotype. That is, underlying differences in phenotype (sex, age, fat mass) may confound the identification of disease-specific markers. The successful identification of proteins related to gender, age and fat mass in this study will allow for promising biomarkers to be tested for potential confounding factors prior to progression into a clinical setting. In addition, findings from this analysis will contribute to improved statistical modeling by including the identified proteins as confounding factors in future biomarker discovery studies.

The strengths of this study include testing whether proteins identified in the MECHE cohort were replicated in the larger DiOGenes cohort. Pathway analysis was also performed using several different pathway analysis software platforms and provided further insights into the functions of the proteins. While the present study represents an important advancement for proteomics there are a number of limitations worth noting. The proteins were identified using SOMAlogic assays which are a subset of the total protein pool. Subsequent versions of SOMAscan or mass spectroscopic methods may identify additional proteins and pathways for each of the phenotypes studied here. In addition, mapping proteins to KEGG, Reactome, and WikiPathways to create meaningful interpretation of the proteomics data is constrained by the depth and publication biases of pathway databases.

\section{Conclusions and Future Outlook}

Phenotypic characteristics such as sex, age, and body fat mass have independent associations with the levels of certain serum proteins. Mapping these proteins to pathways identified biological processes differing across phenotypic measures. Importantly, the findings were replicated in an independent cohort. Gender and sex specific health care is emerging as differences in trajectories toward disease and therapeutic responses between males and females are identified. Many of the most significant proteins identified in this study had known relationships with sex hormone metabolism indicating sex hormones play key roles in influencing metabolic health. Additionally, age and fat mass are well-established risk factors for disease. These results are relevant to the development of diagnostic and prognostic markers of health and disease 
trajectories. The present results will be an important consideration in the development of protein signatures for use in the clinical setting.

\section{ASSOCIATED CONTENT}

\section{S Supporting Information}

The Supporting Information is available free of charge on the ACS Publications website at DOI: 10.1021/acs.jproteome.7b00501.

Figures S1-S7 (PDF)

Tables S1-S8 (ZIP)

\section{AUTHOR INFORMATION}

\section{Corresponding Author}

*E-mail: lorraine.brennan@ucd.ie.

\section{ORCID 1}

Lorraine Brennan: 0000-0002-7711-7499

Present Address

$\boldsymbol{\Delta}_{\text {Vydiant, } 985 \text { 3rd Street, Oakland, California 94601, United }}$ States.

Author Contributions

${ }^{\mathrm{II}} \mathrm{AMC}$ and CFD are joint first authors

Author Contributions

$\mathrm{LB}$ and JK are joint senior authors

Notes

The authors declare no competing financial interest.

\section{ACKNOWLEDGMENTS}

Authors would like to acknowledge participants of both the MECHE and DiOGenes studies. Special thanks to Kei Sakamoto, Sofia Moço, and Loic Dayon from Nestle Institute of Health Sciences and Jan van der Greef from Leiden University for their review of the manuscript. This work was conducted as part of a clinical trial (NCT01172951), funded under the Food for Health Research Initiative (NDP 20072013; 07FHRIUCD1) by the Department of Agriculture, Fisheries and Food (http://www.agriculture.gov.ie/). This research was funded in part by Food for Health Ireland, through Enterprise Ireland Grant No. TC20130001. The DiOGenes project was supported by a contract (FP6-2005513946) from the European Commission Food Quality and Safety Priority of the Sixth Framework Program.

\section{REFERENCES}

(1) Hanash, S. Disease proteomics. Nature 2003, 422 (6928), $226-$ 32.

(2) Anderson, N. L.; Anderson, N. G. The human plasma proteome: history, character, and diagnostic prospects. Mol. Cell. Proteomics 2002, 1 (11), 845-67.

(3) Zethelius, B.; Berglund, L.; Sundstrom, J.; Ingelsson, E.; Basu, S.; Larsson, A.; Venge, P.; Arnlov, J. Use of multiple biomarkers to improve the prediction of death from cardiovascular causes. N. Engl. J. Med. 2008, 358 (20), 2107-16.

(4) American Diabetes Association. Cardiovascular disease and risk management. Diabetes Care 2015, 38, S49-57.

(5) Miike, K.; Aoki, M.; Yamashita, R.; Takegawa, Y.; Saya, H.; Miike, T.; Yamamura, K. Proteome profiling reveals gender differences in the composition of human serum. Proteomics 2010, 10 (14), 2678-91.

(6) Al-Daghri, N. M.; Al-Attas, O. S.; Johnston, H. E.; Singhania, A.; Alokail, M. S.; Alkharfy, K. M.; Abd-Alrahman, S. H.; Sabico, S. L.;
Roumeliotis, T. I.; Manousopoulou-Garbis, A.; Townsend, P. A.; Woelk, C. H.; Chrousos, G. P.; Garbis, S. D. Whole serum 3D LCnESI-FTMS quantitative proteomics reveals sexual dimorphism in the milieu interieur of overweight and obese adults. J. Proteome Res. 2014, 13 (11), 5094-105.

(7) Oberbach, A.; Bluher, M.; Wirth, H.; Till, H.; Kovacs, P.; Kullnick, Y.; Schlichting, N.; Tomm, J. M.; Rolle-Kampczyk, U.; Murugaiyan, J.; Binder, H.; Dietrich, A.; von Bergen, M. Combined proteomic and metabolomic profiling of serum reveals association of the complement system with obesity and identifies novel markers of body fat mass changes. J. Proteome Res. 2011, 10 (10), 4769-88.

(8) Chandramouli, K.; Qian, P. Y. Proteomics: challenges, techniques and possibilities to overcome biological sample complexity. Hum. Genomics Proteomics 2009, 2009, 1.

(9) Gold, L.; Ayers, D.; Bertino, J.; Bock, C.; Bock, A.; Brody, E. N.; Carter, J.; Dalby, A. B.; Eaton, B. E.; Fitzwater, T.; Flather, D.; Forbes, A.; Foreman, T.; Fowler, C.; Gawande, B.; Goss, M.; Gunn, M.; Gupta, S.; Halladay, D.; Heil, J.; Heilig, J.; Hicke, B.; Husar, G.; Janjic, N.; Jarvis, T.; Jennings, S.; Katilius, E.; Keeney, T. R.; Kim, N.; Koch, T. H.; Kraemer, S.; Kroiss, L.; Le, N.; Levine, D.; Lindsey, W.; Lollo, B.; Mayfield, W.; Mehan, M.; Mehler, R.; Nelson, S. K.; Nelson, M.; Nieuwlandt, D.; Nikrad, M.; Ochsner, U.; Ostroff, R. M.; Otis, M.; Parker, T.; Pietrasiewicz, S.; Resnicow, D. I.; Rohloff, J.; Sanders, G.; Sattin, S.; Schneider, D.; Singer, B.; Stanton, M.; Sterkel, A.; Stewart, A.; Stratford, S.; Vaught, J. D.; Vrkljan, M.; Walker, J. J.; Watrobka, M.; Waugh, S.; Weiss, A.; Wilcox, S. K.; Wolfson, A.; Wolk, S. K.; Zhang, C.; Zichi, D. Aptamer-based multiplexed proteomic technology for biomarker discovery. PLoS One 2010, 5 (12), e15004.

(10) Cominetti, O.; Nunez Galindo, A.; Corthesy, J.; Oller Moreno, S.; Irincheeva, I.; Valsesia, A.; Astrup, A.; Saris, W. H.; Hager, J.; Kussmann, M.; Dayon, L. Proteomic Biomarker Discovery in 1000 Human Plasma Samples with Mass Spectrometry. J. Proteome Res. 2016, 15 (2), 389-99.

(11) Morris, C.; O'Grada, C.; Ryan, M.; Roche, H. M.; Gibney, M. J.; Gibney, E. R.; Brennan, L. Identification of differential responses to an oral glucose tolerance test in healthy adults. PLoS One 2013, 8 (8), e72890.

(12) Wallace, M.; Morris, C.; O'Grada, C. M.; Ryan, M.; Dillon, E. T.; Coleman, E.; Gibney, E. R.; Gibney, M. J.; Roche, H. M.; Brennan, L. Relationship between the lipidome, inflammatory markers and insulin resistance. Mol. BioSyst. 2014, 10 (6), 1586-95.

(13) Ryan, M. F.; O’Grada, C. M.; Morris, C.; Segurado, R.; Walsh, M. C.; Gibney, E. R.; Brennan, L.; Roche, H. M.; Gibney, M. J. Withinperson variation in the postprandial lipemic response of healthy adults. Am. J. Clin. Nutr. 2013, 97 (2), 261-7.

(14) Larsen, T. M.; Dalskov, S.; van Baak, M.; Jebb, S.; Kafatos, A.; Pfeiffer, A.; Martinez, J. A.; Handjieva-Darlenska, T.; Kunesova, M.; Holst, C.; Saris, W. H.; Astrup, A. The Diet, Obesity and Genes (Diogenes) Dietary Study in eight European countries - a comprehensive design for long-term intervention. Obes. Rev. 2010, 11 (1), 76-91.

(15) Papadaki, A.; Linardakis, M.; Plada, M.; Larsen, T. M.; van Baak, M. A.; Lindroos, A. K.; Pfeiffer, A. F.; Martinez, J. A.; HandjievaDarlenska, T.; Kunesova, M.; Holst, C.; Saris, W. H.; Astrup, A.; Kafatos, A.; Diet, O.; Genes, P. A multicentre weight loss study using a low-calorie diet over 8 weeks: regional differences in efficacy across eight European cities. Swiss Med. Wkly. 2013, 143, w13721.

(16) Ritchie, M. E.; Phipson, B.; Wu, D.; Hu, Y.; Law, C. W.; Shi, W.; Smyth, G. K. limma powers differential expression analyses for RNAsequencing and microarray studies. Nucleic Acids Res. 2015, 43 (7), e47.

(17) Kutmon, M.; van Iersel, M. P.; Bohler, A.; Kelder, T.; Nunes, N.; Pico, A. R.; Evelo, C. T. PathVisio 3: an extendable pathway analysis toolbox. PLoS Comput. Biol. 2015, 11 (2), e1004085.

(18) Wang, X.; Terfve, C.; Rose, J. C.; Markowetz, F. HTSanalyzeR: an $\mathrm{R} /$ Bioconductor package for integrated network analysis of highthroughput screens. Bioinformatics 2011, 27 (6), 879-80. 
(19) Yu, G.; He, Q. Y. ReactomePA: an R/Bioconductor package for reactome pathway analysis and visualization. Mol. BioSyst. 2016, 12 (2), 477-9.

(20) Liu, S.; Sun, Q. Sex Differences, Endogenous Sex-hormone Hormones, Sex-hormone Binding Globulin (SHBG), and Exogenous Disruptors in Diabetes and Related Metabolic Outcomes. J. Diabetes 2016, DOI: $10.1111 / 1753-0407.12517$.

(21) Geber, S.; Brandao, A. H.; Sampaio, M. Effects of estradiol and FSH on leptin levels in women with suppressed pituitary. Reprod. Biol. Endocrinol. 2012, 10, 45.

(22) Tahboub, R.; Arafah, B. M. Sex steroids and the thyroid. Best Pract Res. Clin Endocrinol Metab 2009, 23 (6), 769-80.

(23) Komukai, K.; Mochizuki, S.; Yoshimura, M. Gender and the renin-angiotensin-aldosterone system. Fundam. Clin. Pharmacol. 2010, 24 (6), 687-98.

(24) Floehr, J.; Dietzel, E.; Neulen, J.; Rosing, B.; Weissenborn, U.; Jahnen-Dechent, W. Association of high fetuin-B concentrations in serum with fertilization rate in IVF: a cross-sectional pilot study. Hum. Reprod. 2016, 31 (3), 630-7.

(25) Strauss, J. F. B., Robert, L. Yen \& Jaffe's Reproductive Endocrinology: Physiology, Pathophysiology, and Clinical Management, 7th ed.; Saunders: Philadelphia, PA, 2014; p 89.

(26) Friedman, J. The long road to leptin. J. Clin. Invest. 2016, 126 (12), 4727-4734.

(27) Volp, A. P.; Barbosa, K. B.; Bressan, J. Nutrients can modulate the adiponectin concentrations in apparently healthy young adult. Nutr. Hosp. 2016, 33 (3), 264.

(28) Meex, R. C.; Hoy, A. J.; Morris, A.; Brown, R. D.; Lo, J. C.; Burke, M.; Goode, R. J.; Kingwell, B. A.; Kraakman, M. J.; Febbraio, M. A.; Greve, J. W.; Rensen, S. S.; Molloy, M. P.; Lancaster, G. I.; Bruce, C. R.; Watt, M. J.; Fetuin, B. Is a Secreted Hepatocyte Factor Linking Steatosis to Impaired Glucose Metabolism. Cell Metab. 2015, 22 (6), 1078-89.

(29) Jiang, H.; Przybyszewski, J.; Mitra, D.; Becker, C.; BrehmStecher, B.; Tentinger, A.; MacDonald, R. S. Soy protein diet, but not Lactobacillus rhamnosus GG, decreases mucin-1, trefoil factor-3, and tumor necrosis factor-alpha in colon of dextran sodium sulfate-treated C57BL/6 mice. J. Nutr. 2011, 141 (7), 1239-46.

(30) Burnier, M. Urinary angiotensinogen and salt sensitivity of blood pressure: the challenge of finding biomarkers of salt-sensitivity. $J$. Hypertens. 2015, 33 (7), 1368-70.

(31) Montenegro, L.; Piscitelli, D.; Giorgio, F.; Covelli, C.; Fiore, M. G.; Losurdo, G.; Iannone, A.; Ierardi, E.; Di Leo, A.; Principi, M. Reversal of IgM deficiency following a gluten-free diet in seronegative celiac disease. World J. Gastroenterol 2014, 20 (46), 17686-9.

(32) Kim, K. O.; Park, H.; Kim, H. S. Effects of High-Protein Diet and/or Resveratrol Supplementation on the Immune Response of Irradiated Rats. Prev. Nutr. Food Sci. 2014, 19 (3), 156-63.

(33) Kische, H.; Gross, S.; Wallaschofski, H.; Volzke, H.; Dorr, M.; Nauck, M.; Haring, R. Clinical correlates of sex hormones in women: The study of health in Pomerania. Metab., Clin. Exp. 2016, 65 (9), 1286-96.

(34) Hara, K.; Yamauchi, T.; Kadowaki, T. Adiponectin: an adipokine linking adipocytes and type 2 diabetes in humans. Curr. Diabetes Rep. 2005, 5 (2), 136-40.

(35) Joyce-Tan, S. M.; Zain, S. M.; Abdul Sattar, M. Z.; Abdullah, N. A. Renin-Angiotensin System Gene Variants and Type 2 Diabetes Mellitus: Influence of Angiotensinogen. J. Diabetes Res. 2016, 2016, 1.

(36) Pimenta, A. F.; Zhukareva, V.; Barbe, M. F.; Reinoso, B. S.; Grimley, C.; Henzel, W.; Fischer, I.; Levitt, P. The limbic systemassociated membrane protein is an Ig superfamily member that mediates selective neuronal growth and axon targeting. Neuron 1995, 15 (2), 287-97.

(37) Hansen, S. W.; Ohtani, K.; Roy, N.; Wakamiya, N. The collectins CL-L1, CL-K1 and CL-P1, and their roles in complement and innate immunity. Immunobiology 2016, 221 (10), 1058-67.

(38) Manttari, S.; Anttila, K.; Jarvilehto, M. Testosterone stimulates myoglobin expression in different muscles of the mouse. J. Comp. Physiol., B 2008, 178 (7), 899-907.
(39) Grandas, O. H.; Mountain, D. J.; Kirkpatrick, S. S.; Rudrapatna, V. S.; Cassada, D. C.; Stevens, S. L.; Freeman, M. B.; Goldman, M. H. Effect of hormones on matrix metalloproteinases gene regulation in human aortic smooth muscle cells. J. Surg. Res. 2008, 148 (1), 94-9.

(40) Katou, M. [Change of serum amyloid P component concentrations in women]. Nihon Sanka Fujinka Gakkai Zasshi 1996, 48 (7), 481-7.

(41) Ali, H. O.; Stavik, B.; Dorum, E.; Iversen, N.; Sandset, P. M.; Skretting, G. Oestrogen induced downregulation of TFPI expression is mediated by ERalpha. Thromb. Res. 2014, 134 (1), 138-43.

(42) Jin, H.; Lin, J.; Fu, L.; Mei, Y. F.; Peng, G.; Tan, X.; Wang, D. M.; Wang, W.; Li, Y. G. Physiological testosterone stimulates tissue plasminogen activator and tissue factor pathway inhibitor and inhibits plasminogen activator inhibitor type 1 release in endothelial cells. Biochem. Cell Biol. 2007, 85 (2), 246-51.

(43) Glueck, C. J.; Friedman, J.; Hafeez, A.; Hassan, A.; Wang, P. Testosterone therapy, thrombophilia, and hospitalization for deep venous thrombosis-pulmonary embolus, an exploratory, hypothesisgenerating study. Med. Hypotheses 2015, 84 (4), 341-3.

(44) Dieplinger, B.; Egger, M.; Poelz, W.; Gabriel, C.; Haltmayer, M.; Mueller, T. Soluble ST2 is not independently associated with androgen and estrogen status in healthy males and females. Clin. Chem. Lab. Med. 2011, 49 (9), 1515-8.

(45) Guo, W.; Bachman, E.; Li, M.; Roy, C. N.; Blusztajn, J.; Wong, S.; Chan, S. Y.; Serra, C.; Jasuja, R.; Travison, T. G.; Muckenthaler, M. U.; Nemeth, E.; Bhasin, S. Testosterone administration inhibits hepcidin transcription and is associated with increased iron incorporation into red blood cells. Aging Cell 2013, 12 (2), 280-91.

(46) Yang, Q.; Jian, J.; Katz, S.; Abramson, S. B.; Huang, X. 17betaEstradiol inhibits iron hormone hepcidin through an estrogen responsive element half-site. Endocrinology 2012, 153 (7), 3170-8.

(47) Yang, X. S.; Huang, D. X.; Li, Z. J. The value of radioimmunoassay of myoglobin in the diagnosis of acute myocardial infarction. Acta Cardiol. 1982, 37 (6), 441-9.

(48) Yamada, Y.; Izawa, H.; Ichihara, S.; Takatsu, F.; Ishihara, H.; Hirayama, H.; Sone, T.; Tanaka, M.; Yokota, M. Prediction of the risk of myocardial infarction from polymorphisms in candidate genes. $\mathrm{N}$. Engl. J. Med. 2002, 347 (24), 1916-23.

(49) Song, Z.; Cai, L.; Guo, L.; Tsukamoto, Y.; Yutani, C.; Li, X. A. Accumulation and expression of serum amyloid $\mathrm{P}$ component in human atherosclerotic lesions. Atherosclerosis 2010, 211 (1), 90-5.

(50) Chen, D.; Xia, M.; Hayford, C.; Tham el, L.; Semik, V.; Hurst, S.; Chen, Y.; Tam, H. H.; Pan, J.; Wang, Y.; Tan, X.; Lan, H. Y.; Shen, H.; Kakkar, V. V.; Xu, Q.; McVey, J. H.; Dorling, A. Expression of human tissue factor pathway inhibitor on vascular smooth muscle cells inhibits secretion of macrophage migration inhibitory factor and attenuates atherosclerosis in ApoE-/- mice. Circulation 2015, 131 (15), 1350-60.

(51) Shang, Q.; Feng, L.; Yu, W.; Xu, J.; Liu, X.; Wang, J. [Proteomics study on ficolin 3 in the human plasma of type 2 diabetics]. Wei Sheng Yan Jiu 2016, 45 (1), 8-13.

(52) Powell, L. W.; Seckington, R. C.; Deugnier, Y. Haemochromatosis. Lancet 2016, 388 (10045), 706-16.

(53) Hagler, L.; Askew, E. W.; Neville, J. R.; Mellick, P. W.; Coppes, R. I., Jr.; Lowder, J. F., Jr. Influence of dietary iron deficiency on hemoglobin, myoglobin, their respective reductases, and skeletal muscle mitochondrial respiration. Am. J. Clin. Nutr. 1981, 34 (10), 2169-77.

(54) Moreno-Navarrete, J. M.; Moreno, M.; Puig, J.; Blasco, G.; Ortega, F.; Xifra, G.; Ricart, W.; Fernandez-Real, J. M. Hepatic iron content is independently associated with serum hepcidin levels in subjects with obesity. Clin. Nutr. 2016, 36 (5), 1434-1439.

(55) Schlater, A. E.; De Miranda, M. A., Jr.; Frye, M. A.; Trumble, S. J.; Kanatous, S. B. Changing the paradigm for myoglobin: a novel link between lipids and myoglobin. J. Appl. Physiol. 2014, 117 (3), 307-15.

(56) Perez-Jimenez, F.; Castro, P.; Lopez-Miranda, J.; Paz-Rojas, E.; Blanco, A.; Lopez-Segura, F.; Velasco, F.; Marin, C.; Fuentes, F.; Ordovas, J. M. Circulating levels of endothelial function are modulated by dietary monounsaturated fat. Atherosclerosis 1999, 145 (2), 351-8. 
(57) Berrettini, M.; Parise, P.; Ricotta, S.; Iorio, A.; Peirone, C.; Nenci, G. G. Increased plasma levels of tissue factor pathway inhibitor (TFPI) after $\mathrm{n}-3$ polyunsaturated fatty acids supplementation in patients with chronic atherosclerotic disease. Thromb. Haemost. 1996, 75 (3), 395-400.

(58) Grober, U.; Reichrath, J.; Holick, M. F.; Kisters, K. Vitamin K: an old vitamin in a new perspective. Derm.-Endocrinol. 2014, 6 (1), e968490.

(59) Citelli, M.; Bittencourt, L. L.; da Silva, S. V.; Pierucci, A. P.; Pedrosa, C. Vitamin A modulates the expression of genes involved in iron bioavailability. Biol. Trace Elem. Res. 2012, 149 (1), 64-70.

(60) Moro, T.; Nakao, S.; Sumiyoshi, H.; Ishii, T.; Miyazawa, M.; Ishii, N.; Sato, T.; Iida, Y.; Okada, Y.; Tanaka, M.; Hayashi, H.; Ueha, S.; Matsushima, K.; Inagaki, Y. A Combination of Mitochondrial Oxidative Stress and Excess Fat/Calorie Intake Accelerates Steatohepatitis by Enhancing Hepatic CC Chemokine Production in Mice. PLoS One 2016, 11 (1), e0146592.

(61) Ricklin, D.; Lambris, J. D. Complement in immune and inflammatory disorders: pathophysiological mechanisms. J. Immunol. 2013, 190 (8), 3831-8.

(62) Kokawa, T.; Abumiya, T.; Kimura, T.; Harada-Shiba, M.; Koh, H.; Tsushima, M.; Yamamoto, A.; Kato, H. Tissue factor pathway inhibitor activity in human plasma. Measurement of lipoproteinassociated and free forms in hyperlipidemia. Arterioscler., Thromb., Vasc. Biol. 1995, 15 (4), 504-10.

(63) Griffin, J. H.; Gruber, A.; Fernandez, J. A. Reevaluation of total, free, and bound protein $\mathrm{S}$ and C4b-binding protein levels in plasma anticoagulated with citrate or hirudin. Blood 1992, 79 (12), 3203-11.

(64) Liberti, G.; Bertina, R. M.; Rosendaal, F. R. Hormonal state rather than age influences cut-off values of protein $S$ : reevaluation of the thrombotic risk associated with protein $S$ deficiency. Thromb. Haemost. 1999, 82 (3), 1093-6.

(65) Anderson, H. A.; Maylock, C. A.; Williams, J. A.; Paweletz, C. P.; Shu, H.; Shacter, E. Serum-derived protein $S$ binds to phosphatidylserine and stimulates the phagocytosis of apoptotic cells. Nat. Immunol. 2003, 4 (1), 87-91.

(66) Triantafilou, M.; Hughes, T. R.; Morgan, B. P.; Triantafilou, K. Complementing the inflammasome. Immunology 2016, 147 (2), 15264.

(67) Logue, J.; Walker, J. J.; Colhoun, H. M.; Leese, G. P.; Lindsay, R. S.; McKnight, J. A.; Morris, A. D.; Pearson, D. W.; Petrie, J. R.; Philip, S.; Wild, S. H.; Sattar, N. Scottish Diabetes Research Network Epidemiology, G., Do men develop type 2 diabetes at lower body mass indices than women? Diabetologia 2011, 54 (12), 3003-6.

(68) Geer, E. B.; Shen, W. Gender differences in insulin resistance, body composition, and energy balance. Gender Med. 2009, 6 (Suppl 1), $60-75$.

(69) Feldman, H. A.; Longcope, C.; Derby, C. A.; Johannes, C. B.; Araujo, A. B.; Coviello, A. D.; Bremner, W. J.; McKinlay, J. B. Age trends in the level of serum testosterone and other hormones in middle-aged men: longitudinal results from the Massachusetts male aging study. J. Clin. Endocrinol. Metab. 2002, 87 (2), 589-98.

(70) Menni, C.; Kiddle, S. J.; Mangino, M.; Vinuela, A.; Psatha, M.; Steves, C.; Sattlecker, M.; Buil, A.; Newhouse, S.; Nelson, S.; Williams, S.; Voyle, N.; Soininen, H.; Kloszewska, I.; Mecocci, P.; Tsolaki, M.; Vellas, B.; Lovestone, S.; Spector, T. D.; Dobson, R.; Valdes, A. M. Circulating Proteomic Signatures of Chronological Age. J. Gerontol., Ser. A 2015, 70 (7), 809-16.

(71) Kurt, I.; Abasli, D.; Cihan, M.; Serdar, M. A.; Olgun, A.; Saruhan, E.; Erbil, M. K. Chitotriosidase levels in healthy elderly subjects. Ann. N. Y. Acad. Sci. 2007, 1100, 185-8.

(72) Verma, P.; Dalal, K. ADAMTS-4 and ADAMTS-5: key enzymes in osteoarthritis. J. Cell. Biochem. 2011, 112 (12), 3507-14.

(73) Zhao, C. Q.; Zhang, Y. H.; Jiang, S. D.; Li, H.; Jiang, L. S.; Dai, L. Y. ADAMTS-5 and intervertebral disc degeneration: the results of tissue immunohistochemistry and in vitro cell culture. J. Orthop. Res. 2011, 29 (5), 718-25.

(74) Malaguarnera, L.; Ohazuruike, L. N.; Tsianaka, C.; Antic, T.; Di Rosa, M.; Malaguarnera, M. Human chitotriosidase polymorphism is associated with human longevity in Mediterranean nonagenarians and centenarians. J. Hum. Genet. 2010, 55 (1), 8-12.

(75) Teumer, A.; Qi, Q.; Nethander, M.; Aschard, H.; Bandinelli, S.; Beekman, M.; Berndt, S. I.; Bidlingmaier, M.; Broer, L.; Group, C. L. W.; Cappola, A.; Ceda, G. P.; Chanock, S.; Chen, M. H.; Chen, T. C.; Chen, Y. D.; Chung, J.; Del Greco Miglianico, F.; Eriksson, J.; Ferrucci, L.; Friedrich, N.; Gnewuch, C.; Goodarzi, M. O.; Grarup, N.; Guo, T.; Hammer, E.; Hayes, R. B.; Hicks, A. A.; Hofman, A.; HouwingDuistermaat, J. J.; Hu, F.; Hunter, D. J.; Husemoen, L. L.; Isaacs, A.; Jacobs, K. B.; Janssen, J. A.; Jansson, J. O.; Jehmlich, N.; Johnson, S.; Juul, A.; Karlsson, M.; Kilpelainen, T. O.; Kovacs, P.; Kraft, P.; Li, C.; Linneberg, A.; Liu, Y.; Loos, R. J.; Body Composition Genetics, C.; Lorentzon, M.; Lu, Y.; Maggio, M.; Magi, R.; Meigs, J.; Mellstrom, D.; Nauck, M.; Newman, A. B.; Pollak, M. N.; Pramstaller, P. P.; Prokopenko, I.; Psaty, B. M.; Reincke, M.; Rimm, E. B.; Rotter, J. I.; Saint Pierre, A.; Schurmann, C.; Seshadri, S.; Sjogren, K.; Slagboom, P. E.; Strickler, H. D.; Stumvoll, M.; Suh, Y.; Sun, Q.; Zhang, C.; Svensson, J.; Tanaka, T.; Tare, A.; Tonjes, A.; Uh, H. W.; van Duijn, C. M.; van Heemst, D.; Vandenput, L.; Vasan, R. S.; Volker, U.; Willems, S. M.; Ohlsson, C.; Wallaschofski, H.; Kaplan, R. C. Genomewide meta-analysis identifies loci associated with IGF-I and IGFBP-3 levels with impact on age-related traits. Aging Cell 2016, 15 (5), 811-24.

(76) Johnston, A.; Xing, X.; Guzman, A. M.; Riblett, M.; Loyd, C. M.; Ward, N. L.; Wohn, C.; Prens, E. P.; Wang, F.; Maier, L. E.; Kang, S.; Voorhees, J. J.; Elder, J. T.; Gudjonsson, J. E. IL-1F5, -F6, -F8, and -F9: a novel IL-1 family signaling system that is active in psoriasis and promotes keratinocyte antimicrobial peptide expression. J. Immunol. 2011, 186 (4), 2613-22.

(77) Fosang, A. J.; Little, C. B. Drug insight: aggrecanases as therapeutic targets for osteoarthritis. Nat. Clin. Pract. Rheumatol. 2008, $4(8), 420-7$.

(78) Evans, D. S.; Cailotto, F.; Parimi, N.; Valdes, A. M.; CastanoBetancourt, M. C.; Liu, Y.; Kaplan, R. C.; Bidlingmaier, M.; Vasan, R. S.; Teumer, A.; Tranah, G. J.; Nevitt, M. C.; Cummings, S. R.; Orwoll, E. S.; Barrett-Connor, E.; Renner, J. B.; Jordan, J. M.; Doherty, M.; Doherty, S. A.; Uitterlinden, A. G.; van Meurs, J. B.; Spector, T. D.; Lories, R. J.; Lane, N. E. Genome-wide association and functional studies identify a role for IGFBP3 in hip osteoarthritis. Ann. Rheum. Dis. 2015, 74 (10), 1861-7.

(79) Yamaguchi, T.; Kanatani, M.; Yamauchi, M.; Kaji, H.; Sugishita, T.; Baylink, D. J.; Mohan, S.; Chihara, K.; Sugimoto, T. Serum levels of insulin-like growth factor (IGF); IGF-binding proteins-3, -4, and -5; and their relationships to bone mineral density and the risk of vertebral fractures in postmenopausal women. Calcif. Tissue Int. 2006, 78 (1), $18-24$.

(80) Rutter, M. M.; Markoff, E.; Clayton, L.; Akeno, N.; Zhao, G.; Clemens, T. L.; Chernausek, S. D. Osteoblast-specific expression of insulin-like growth factor-1 in bone of transgenic mice induces insulinlike growth factor binding protein-5. Bone 2005, 36 (2), 224-31.

(81) Kim, J. G.; Sun, B. H.; Dietrich, M. O.; Koch, M.; Yao, G. Q.; Diano, S.; Insogna, K.; Horvath, T. L. AgRP Neurons Regulate Bone Mass. Cell Rep. 2015, 13 (1), 8-14.

(82) Wendel, M.; Sommarin, Y.; Heinegard, D. Bone matrix proteins: isolation and characterization of a novel cell-binding keratan sulfate proteoglycan (osteoadherin) from bovine bone. J. Cell Biol. 1998, 141 (3), 839-47.

(83) Argyropoulos, G.; Rankinen, T.; Neufeld, D. R.; Rice, T.; Province, M. A.; Leon, A. S.; Skinner, J. S.; Wilmore, J. H.; Rao, D. C.; Bouchard, C. A polymorphism in the human agouti-related protein is associated with late-onset obesity. J. Clin. Endocrinol. Metab. 2002, 87 (9), 4198-202.

(84) Corfitsen, H. T.; Drago, A. Insight gained from genome-wide interaction and enrichment analysis on weight gain during citalopram treatment. Neurosci. Lett. 2017, 637, 38-43.

(85) Waters, D. L.; Yau, C. L.; Montoya, G. D.; Baumgartner, R. N. Serum Sex Hormones, IGF-1, and IGFBP3 Exert a Sexually Dimorphic Effect on Lean Body Mass in Aging. J. Gerontol., Ser. A 2003, 58 (7), 648-52. 
(86) Kheiroddin, P.; Rasihashemi, S. Z.; Estiar, M. A.; Mahmudian, B.; Halimi, M.; Mousavi, F.; Nemati, M.; Sakhinia, E.; Gene, R. E. T. Analysis in Patients with Medullary Thyroid Carcinoma. Clin. Lab. 2016, 62 (5), 871-6.

(87) Huang, S. P.; Levesque, E.; Guillemette, C.; Yu, C. C.; Huang, C. Y.; Lin, V. C.; Chung, I. C.; Chen, L. C.; Laverdiere, I.; Lacombe, L.; Fradet, Y.; Chang, T. Y.; Lee, H. Z.; Juang, S. H.; Bao, B. Y. Genetic variants in microRNAs and microRNA target sites predict biochemical recurrence after radical prostatectomy in localized prostate cancer. Int. J. Cancer 2014, 135 (11), 2661-7.

(88) Naspi, A.; Zingariello, M.; Sancillo, L.; Panasiti, V.; Polinari, D.; Martella, M.; Rosa Alba, R.; Londei, P. IGFBP-3 inhibits Wnt signaling in metastatic melanoma cells. Mol. Carcinog. 2017, 56 (2), 681-693.

(89) Butt, A. J.; Dickson, K. A.; McDougall, F.; Baxter, R. C. Insulinlike growth factor-binding protein-5 inhibits the growth of human breast cancer cells in vitro and in vivo. J. Biol. Chem. 2003, 278 (32), 29676-85.

(90) Spangenburg, E. E.; Abraha, T.; Childs, T. E.; Pattison, J. S.; Booth, F. W. Skeletal muscle IGF-binding protein-3 and -5 expressions are age, muscle, and load dependent. Am. J. Physiol Endocrinol Metab 2003, 284 (2), E340-50.

(91) Kang, J. S.; Mulieri, P. J.; Hu, Y.; Taliana, L.; Krauss, R. S. BOC, an Ig superfamily member, associates with $\mathrm{CDO}$ to positively regulate myogenic differentiation. EMBO J. 2002, 21 (1-2), 114-24.

(92) Lokiec, K.; Blonska, A.; Walecka-Kapica, E.; Stec-Michalska, K. [Effect of treatment with diet on reducing levels of sex hormones in perimenopausal women with overweight and obesity]. Pol Merkur Lekarski 2016, 40 (240), 362-8.

(93) Briggs, D. I.; Lockie, S. H.; Wu, Q.; Lemus, M. B.; Stark, R.; Andrews, Z. B. Calorie-restricted weight loss reverses high-fat dietinduced ghrelin resistance, which contributes to rebound weight gain in a ghrelin-dependent manner. Endocrinology 2013, 154 (2), 709-17.

(94) Gholamhosseini, S.; Nematipour, E.; Djazayery, A.; Javanbakht, M. H.; Koohdani, F.; Zareei, M.; Djalali, M. omega-3 fatty acid differentially modulated serum levels of IGF1 and IGFBP3 in men with CVD: a randomized, double-blind placebo-controlled study. Nutrition 2015, 31 (3), 480-4.

(95) Caliezi, C.; Wuillemin, W. A.; Zeerleder, S.; Redondo, M.; Eisele, B.; Hack, C. E. C1-Esterase inhibitor: an anti-inflammatory agent and its potential use in the treatment of diseases other than hereditary angioedema. Pharmacol. Rev. 2000, 52 (1), 91-112.

(96) Andriani, G. A.; Almeida, V. P.; Faggioli, F.; Mauro, M.; Tsai, W. L.; Santambrogio, L.; Maslov, A.; Gadina, M.; Campisi, J.; Vijg, J.; Montagna, C. Whole Chromosome Instability induces senescence and promotes SASP. Sci. Rep. 2016, 6, 35218.

(97) Villeda, S. A.; Luo, J.; Mosher, K. I.; Zou, B.; Britschgi, M.; Bieri, G.; Stan, T. M.; Fainberg, N.; Ding, Z.; Eggel, A.; Lucin, K. M.; Czirr, E.; Park, J. S.; Couillard-Despres, S.; Aigner, L.; Li, G.; Peskind, E. R.; Kaye, J. A.; Quinn, J. F.; Galasko, D. R.; Xie, X. S.; Rando, T. A.; WyssCoray, $\mathrm{T}$. The ageing systemic milieu negatively regulates neurogenesis and cognitive function. Nature 2011, 477 (7362), 90-4.

(98) Lefebvre, J. S.; Maue, A. C.; Eaton, S. M.; Lanthier, P. A.; Tighe, M.; Haynes, L. The aged microenvironment contributes to the agerelated functional defects of CD4 T cells in mice. Aging Cell 2012, 11 (5), 732-40.

(99) Monti, D.; Ostan, R.; Borelli, V.; Castellani, G.; Franceschi, C. Inflammaging and human longevity in the omics era. Mech. Ageing Dev. 2016, 165, 129.

(100) Friedman, J. M.; Halaas, J. L. Leptin and the regulation of body weight in mammals. Nature 1998, 395 (6704), 763-70.

(101) Baile, C. A.; Della-Fera, M. A.; Martin, R. J. Regulation of metabolism and body fat mass by leptin. Annu. Rev. Nutr. 2000, 20, 105-27.

(102) Spiegelman, B. M.; Flier, J. S. Obesity and the regulation of energy balance. Cell 2001, 104 (4), 531-43.

(103) Jequier, E. Leptin signaling, adiposity, and energy balance. Ann. N. Y. Acad. Sci. 2002, 967, 379-88.

(104) Al-Hamodi, Z.; Ismail, I. S.; Saif-Ali, R.; Ahmed, K. A.; Muniandy, S. Association of plasminogen activator inhibitor-1 and tissue plasminogen activator with type 2 diabetes and metabolic syndrome in Malaysian subjects. Cardiovasc. Diabetol. 2011, 10, 23.

(105) Svendsen, O. L.; Hassager, C.; Christiansen, C.; Nielsen, J. D.; Winther, K. Plasminogen activator inhibitor-1, tissue-type plasminogen activator, and fibrinogen: Effect of dieting with or without exercise in overweight postmenopausal women. Arterioscler., Thromb., Vasc. Biol. 1996, 16 (3), 381-5.

(106) Ahmed, R. L.; Thomas, W.; Schmitz, K. H. Interactions between insulin, body fat, and insulin-like growth factor axis proteins. Cancer Epidemiol., Biomarkers Prev. 2007, 16 (3), 593-7.

(107) Ge, H.; Gardner, J.; Wu, X.; Rulifson, I.; Wang, J.; Xiong, Y.; Ye, J.; Belouski, E.; Cao, P.; Tang, J.; Lee, K. J.; Coberly, S.; Gupte, J.; Miao, L.; Yang, L.; Nguyen, N.; Shan, B.; Yeh, W. C.; Veniant, M. M.; Li, Y.; Baribault, H. Trefoil Factor 3 (TFF3) Is Regulated by Food Intake, Improves Glucose Tolerance and Induces Mucinous Metaplasia. PLoS One 2015, 10 (6), e0126924.

(108) Hertle, E.; Stehouwer, C. D.; van Greevenbroek, M. M. The complement system in human cardiometabolic disease. Mol. Immunol. 2014, 61 (2), 135-48.

(109) Zhang, J.; Wright, W.; Bernlohr, D. A.; Cushman, S. W.; Chen, $\mathrm{X}$. Alterations of the Classic Pathway of Complement in Adipose Tissue of Obesity and Insulin Resistance. FASEB J. 2007, 21 (5), A294-A294.

(110) Xia, J.; Zhang, Y.; Xin, L.; Kong, S.; Chen, Y.; Yang, S.; Li, K. Global Transcriptomic Profiling of Cardiac Hypertrophy and Fatty Heart Induced by Long-Term High-Energy Diet in Bama Miniature Pigs. PLoS One 2015, 10 (7), e0132420.

(111) Zeng, W.; Pirzgalska, R. M.; Pereira, M. M.; Kubasova, N.; Barateiro, A.; Seixas, E.; Lu, Y. H.; Kozlova, A.; Voss, H.; Martins, G. G.; Friedman, J. M.; Domingos, A. I. Sympathetic neuro-adipose connections mediate leptin-driven lipolysis. Cell 2015, 163 (1), 84-94.

(112) Briot, A.; Civelek, M.; Seki, A.; Hoi, K.; Mack, J. J.; Lee, S. D.; Kim, J.; Hong, C.; Yu, J.; Fishbein, G. A.; Vakili, L.; Fogelman, A. M.; Fishbein, M. C.; Lusis, A. J.; Tontonoz, P.; Navab, M.; Berliner, J. A.; Iruela-Arispe, M. L. Endothelial NOTCH1 is suppressed by circulating lipids and antagonizes inflammation during atherosclerosis. J. Exp. Med. 2015, 212 (12), 2147-63. 